\title{
SiM
}

\section{Rangelands in the Classroom: Increasing Rangeland Understanding of Students and Teachers}

\author{
By Karen Launchbaugh, Stephanie Bestelmeyer, and Gretchen Hyde
}

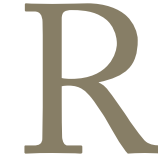

angeland professionals are passionate about rangelands, and they want people in their communities to know what rangelands are and the many resources rangelands offer. Teachers are equally passionate about helping their students become good citizens who will make productive contributions to the world in which they live. For many teachers, this endeavor includes helping their students understand the landscapes that surround them. There are many opportunities for those who care about rangelands to partner with educators to help students gain appreciation, understanding, and fascination with the wild open spaces we know as rangelands.

Many educators and rangeland professionals have a strong common interest in helping children and adults learn about the landscapes on which they live, work, and play. However, efforts to address this common interest are becoming increasingly difficult as our population becomes more and more urbanized and electronic. The decreased daily interactions between children and the wild and natural landscapes that surround them has given rise to a modern concern over a "nature deficit disorder," highlighted by writer Richard Louv in his book Last Child in the Woods. ${ }^{1}$ Youth education programs focused on rangelands offer a possible way to address this common interest and concern.

In this article, we will acknowledge challenges and outline opportunities to increase exposure of students to rangeland topics while they are in elementary school, middle school, and high school. We hope that successes in this endeavor will increase the rangeland literacy of tomorrow's citizens and increase their daily interactions with, and appreciation for, rangelands.

\section{Why Range Professionals Want Rangeland Education for Students}

Rangeland management embraces the care and stewardship of land to meet the needs of society. There may have been a time, decades ago, when meeting "the needs of society" was relatively simple and largely focused on working with ranchers to produce meat, wool, and leather. The modern era of rangeland management, however, requires an ability to manage land for a much wider variety of ecological services for a more diverse set of societal needs and desires.

In this modern era, rangeland professionals need an informed citizenry to give guidance and provide support for proposed actions. Most range professionals wish for a greater understanding of rangelands among those who graze and recreate on rangelands, read the news, and vote. Sometimes this hope reflects a pragmatic desire for people to understand their own impacts on the land and have appreciation for the stewardship efforts of those who manage rangelands. Other times, desires to increase understanding of rangelands are aimed simply at sharing a profound love for rangelands that seem "hidden in plain sight" to most people. Regardless of the motives, increasing understanding of rangelands would enhance the conservation and management of rangelands. This goal inevitably leads to the desire to increase the coverage of rangeland topics in kindergarten through 12th grade $(\mathrm{K}-12)$ textbooks, classroom activities, and field events.

\section{Many Teachers Want Their Students to} Understand the Landscapes in Which They Live

We see a growing concern about the divide between schools and the communities and environments that surround them, which has given rise to an educational paradigm called "place-based education." Today, children often seem disconnected from the world outside their doors and are more connected to electronic gadgets, computer interfaces, and video-based experiences. Place-based education seeks to teach language arts, mathematics, social studies, science, and other subjects across the curriculum in ways that incorporate unique aspects of the local community and environment. When applied to studies of the schoolyard or surrounding areas, it helps dispel many students' misperceptions that "nature" can only be found far away from human activities and that humans are not part of the ecosystem.

Place-based education is a powerful idea on which to build rangeland education programs because most people live in or near rangeland landscapes or agricultural areas that were once 
rangelands. Nearly half of the land surface on earth is rangeland, and nearly half of the 18 western states in the United States comprise rangelands. Thus, rangelands offer a gateway for students to build a foundational understanding of their local environment. With that foundation, students can then broaden their perspectives and make connections to other parts of the world, such as Australia and Africa, where more than $75 \%$ of land is characterized as rangeland. Rangelands are great places to learn about the climate, soils, vegetation, and plants that create the landscapes in which most westerners, live, work, and play.

The study of rangelands is inherently multidisciplinary because a true understanding of rangeland management requires knowledge of not only science but also math, history, politics, and economics. Although standardized testing and other barriers often make it difficult, teachers are being encouraged to engage their students in project-based learning and other forms of multidisciplinary projects. Rangeland education programs can, therefore, provide rich examples that tie into educational needs.

\section{Helping Teachers Meet Their Goals and Objectives}

Today's educational environment is filled with standardized procedures, required tests, and specified teaching objectives in the era after the "No Child Left Behind" act. It behooves those who want to increase information about rangelands in today's classrooms to understand this modern reality and help teachers meet these daily requirements. For example, each state has a series of grade-specific educational standards that must be addressed each year. Teachers are under considerable time pressure to make sure they teach each standard, which means, to be implemented widely, almost every classroom exercise or field activity must show direct alignment with existing standards.

Unfortunately, there are very few standards in any state that directly address rangelands. It is, therefore, up to rangeland professionals to help teachers understand how teaching about rangelands can address many of their existing standards. Fortunately, rangeland topics and activities can be developed to address many of these educational standards, including reading and writing about rangelands to address language arts standards, state history centered around the development of rangelands to address social studies standards, and measuring and monitoring rangelands in a way that incorporates mathematics and science standards.

Until recently, each state had its own process for developing and implementing standards, making alignment of activities with state standards difficult and time consuming. However, "Common Core Standards" for language arts and mathematics have now been adopted by most states. ${ }^{i}$ This will result in greater opportunity for rangeland education activities that are aligned with Common Core Standards to be used by educators throughout the country, perhaps with modifications to make sure the activity addresses local rangeland issues.

For more information on the Common Core State Standards Initiative, see http://www.corestandards.org.

\section{Providing Educational Materials for} Classrooms, Laboratories, and Field Activities Well-designed, up-to-date, and engaging educational materials are essential to provide a necessary foundation and to interest students in rangeland topics. Our review of dozens of history and biology textbooks revealed almost no mention of rangelands. Textbooks that focus on ecology and environmental science for high-school students often include a discussion of grasslands, deserts, and savannas, although these are not usually described with the word rangeland. An even more horrifying reality for rangeland professionals is that discussions of rangeland in high-school textbooks and related Internet sites are usually related to overgrazing, weed infestations, and desertification.

Several good activity guides and classroom protocols are available for teachers that focus on general environmental-science topics or specific resources. These include Project WILD (Houston, TX), ${ }^{\text {ii }}$ Project Learning Tree (Washington, DC), iii and Project Wet (Bozeman, MT). ${ }^{\text {iv }}$ These programs offer many excellent activities that facilitate exercises and encourage teachers to get students out in nature. This accomplishes a primary goal for rangeland education. However, these programs and activities seldom evoke the name rangeland. Therefore, students may be learning a lot about rangelands but be unable to connect what they learn to what they hear in the media or conversations about rangelands. It is also essential that rangescience activities engage students in the full scientific process, allowing students to not only collect data but also to analyze those data, form conclusions, and then share those conclusions with their peers or other audiences.

The Idaho Rangeland Resource Commission (IRRC, Emmet, ID) and the University of Idaho (Moscow, ID) rangeland program have been working together for more than a decade to create class materials and activities focused on rangelands. This collaboration has created dozens of range activities for $\mathrm{K}-12$ classrooms tied to Idaho Achievement Standards and posted on the IRRC Web site. ${ }^{\mathrm{V}}$ This partnership has also created a rangeland curriculum and teacher resource guide for high-school classrooms with reading resources, classroom presentations, and activities. ${ }^{\mathrm{vi}}$

Natural resource and land management agencies are also creating outstanding resources for teachers to use in their classrooms, school yards, and surrounding landscapes. For example, the Bureau of Land Management (BLM) has created educational resources on riparian areas, deserts, wild horses, and many other rangeland topics as part of their "Learning Landscapes" program. ${ }^{\text {vii }}$ The U.S. Forest Service (USFS) has created a multifaceted program called "Celebrating Wild-

\footnotetext{
ii For more information on Project Wild, see http://www.projectwild.org.

iii For more information on Project Learning Tree, see http://www.plt.org.

iv For more information on Project Wet, see http://www.projectwet.org.

${ }^{v}$ For more information on the IRRC, see http://idrange.org.

vi The Teacher Resource Guide for Rangeland Principles is available at: http://www.cnr.uidaho.edu/what-is-range/Curriculum/.

vii BLM's "Learning Landscapes" program is available at: http://www.blm. gov/wo/st/en/res/Education_in_BLM/Learning_Landscapes.html.
} 
flowers" that can be applied to teach ecological principles and captivate student interest of rangelands. viii Each state of the Natural Resources Conservation Service (NRCS) provides information about soils, plants, and climate in their link called "For Teachers and Students" on every state Web site. ${ }^{\text {ix }}$

The challenge of getting range-specific material in the hands of teachers and students is significant. If those who care for rangelands want to make sure range is covered in a regular and systematic way, then we range enthusiasts must create teaching resources. A superb example of meeting this challenge is the Rangeland Idaho's Roots book and activity produced by the IRRC. A unit on Idaho History is a part of every fourth grade classroom in Idaho. The IRRC saw this as an opportunity to help students understand what rangelands are and their important role in the history of Idaho. The IRRC began by creating a full-color, 8-page booklet titled Rangeland Idaho's Roots. In this wonderfully illustrated booklet, students are drawn through changes in Idaho that include dominance of wooly mammoths, Native American land uses, exploration by trappers, development by pioneers on the Oregon Trail who passed through Idaho, homesteaders who settled in Idaho, and ranchers who started grazing cattle and sheep more than a century ago and continue today. The booklet even illustrates how science is applied in the modern field of rangeland management. Idaho teachers and others can request copies of the booklet for their classrooms through the IRRC Web site, ${ }^{\mathrm{x}}$ which comes with a teacher's guide and classroom activities that are correlated with the state achievement standards. The IRRC distributes 12,000 to 15,000 booklets each year to schools throughout the state.

\section{Offer Students and Teachers Field Opportunities}

One of the best ways to capture the interest and attention of students is to get them out on the range. This is an admirable, but difficult, goal to achieve given the limited financial resources facing education, liability concerns over student safety, and a need to meet educational standards. In New Mexico, a unique partnership between the USDA-ARS Jornada Experimental Range and the nonprofit Asombro Institute for Science Education has resulted in a highly successful program that faces this challenge with a bold step forward into the Chihuahuan Desert. ${ }^{\text {xi }}$ More than 3,000 K-12 students attend full-day field trips to the Jornada Experimental Range and adjacent Chihuahuan Desert Nature Park each year. They rotate through four hands-on activity stations that have been chosen by their teachers from a menu of 38 stations in four grade levels (K-second, third-fifth, sixth-eighth, and ninth-12th). Stations have

\footnotetext{
viii The USFS "Celebrating Wildflowers" program is available at: http:// www.fs.fed.us/wildflowers/

${ }^{i x}$ NRCS provides resources for teachers and students on their Web site http:// www.nrcs.usda.gov, under "Browse by Audience, Teachers and Students." xIRRC, http://idrange.org/

xi For more information on the Asombro Institute for Science Education, see http://www.asombro.org.
}

been developed with the assistance of Jornada Experimental Range scientists. These activity stations are often small-scale versions of local experiments and are aligned with state education standards. The Asombro Institute for Science Education receives grants from foundations and businesses to help defray bus costs, ensuring that cost is not a barrier for participation.

\section{Providing Teachers With Rangeland Training}

Teachers are exceptionally creative professionals who can take information in nearly every form and make it useful to their students. This innovation is probably driven by their strong desire to help their students learn and succeed. However, in our interactions with teachers, we have learned that teachers, like most of the rest of us, prefer to emphasize topics with which they are most familiar. It is clear that rangeland topics are often not included in $\mathrm{K}-12$ classrooms simply because the teachers are not familiar with what rangelands are and how they work. Workshops designed for teachers are an effective way to help teachers gain both familiarity with rangeland topics and the confidence to present these topics to their students.

Teachers are often required to take continuing education classes from colleges and universities. This requirement provides a great opportunity to help teachers experience rangelands and learn about resources available to bring rangelands into the classroom. The IRRC is just one example of an organization that partners with a university (the University of Idaho) to offer teacher workshops for which teachers can gain necessary teacher continuing education credits. Unfortunately, university rangeland programs often overlook this great opportunity. Only a handful of universities offer continuing education workshops that focus on rangeland topics in their state.

Relationships between university rangeland professors and high-school teachers can have significant outcomes. Recent trends in education have encouraged high-school administrators and educators to partner with university programs to offer advanced placement, concurrent enrollment, or dualcredit courses where students in high school can earn university credit. Opportunities exist to create partnerships between high schools and universities to offer courses in ecology, environmental science, and natural resources with a significant focus on rangelands. Courses focused exclusively on rangelands can also be offered, such as the Rangeland Principles course, created through a partnership between the University of Idaho, the IRRC, and high-school vocational agriculture teachers. ${ }^{\text {xii }}$ This course and others will ensure that students have opportunities to build significant knowledge of, and appreciation for, rangelands while in high school.

Rangeland Education From Here to the Future Increasing rangeland topics in youth education is a laudable goal for those who care about and manage rangelands. This desire to advance rangeland literacy can be accomplished by

\footnotetext{
xi Information on the Rangeland Principles course can be accessed at http://www.cnr.uidaho.edu/rem251/.
} 
increasing rangeland topics in reading resources, classroom activities, field opportunities, and teacher competency. The path to increasing rangeland understanding among students from kindergarten through high school is a hope and a challenge to the rangeland profession. The key to smoothing this path toward greater student understanding of rangelands includes creating relevant and engaging classroom materials, making education resources widely and freely available, facilitating teachers, and providing teacher education.

For those who care about rangelands and want to see more information in schools, the first step is to start a conversation with teachers and administrators in your local schools. Find out what is being covered and look for voids and opportunities that could be filled with rangeland topics. Perhaps it is time for the rangeland profession and the SRM to step forward and build a road map of resources and opportunities to the future. The key is to make it easy for students and teachers. Range education materials and programs need to help teachers effectively use their time with students to address educational goals. Rangeland topics must become implicit in the work of teachers, not an extra book or activity to try to pile on the top of an already full education calendar.

Efforts to include rangelands in the classroom and curriculum will increase the knowledge of citizens living on and enjoying our nation's rangelands. Who knows, we may even inspire the next generation of college students and future rangeland managers and scientists.

\section{References}

1. Louv, R. 2008. Last child in the woods: saving our children from nature-deficit disorder. New York, NY, USA: Workman Publishing Co. 345 p.

\begin{abstract}
Authors are Professor, Dept of Forest, Rangeland, and Fire Sciences, University of Idaho, Moscow, ID 83844,USA, klaunchb@ uidaho.edu (Launchbaugh); Director, Asombro Institute for Science Education, Las Cruces, NM 88004, USA (Bestelmeyer); and Executive Director, Idaho Rangeland Resource Commission, Emmett, ID 83617, USA (Hyde).
\end{abstract}

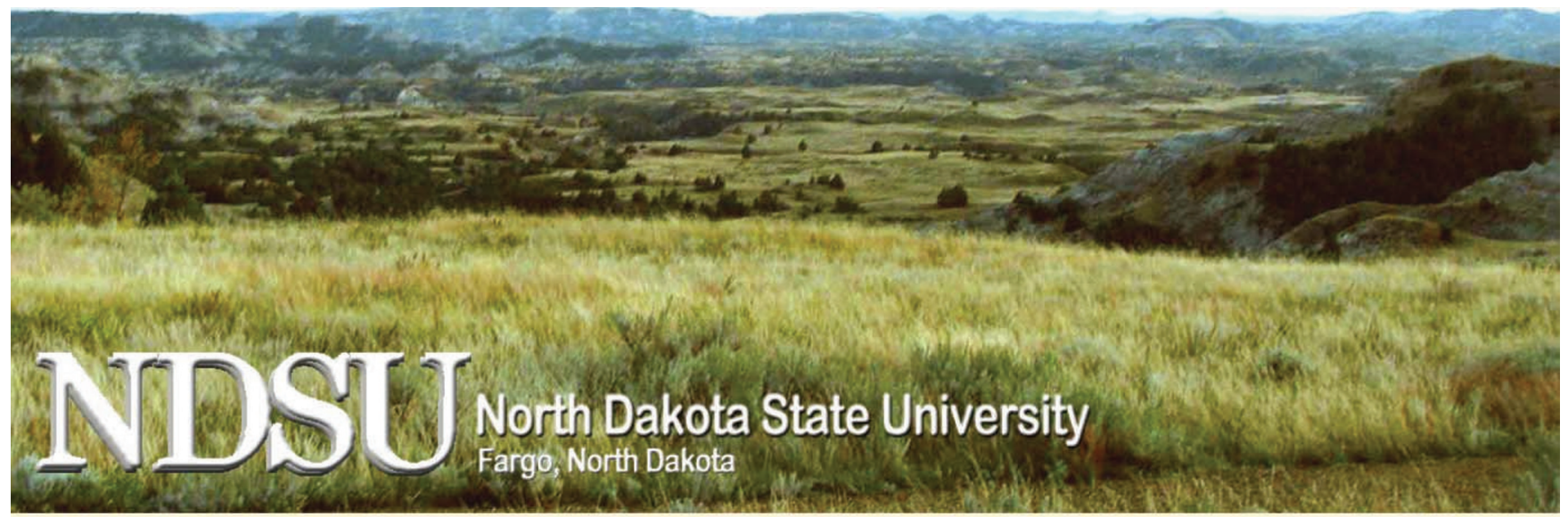

Range Science, a program in the School of Natural Resource Sciences at NDSU, offers the following degrees: Bachelor of Science, Master of Science and Doctor of Philosophy. Our program deals with the interrelationships among plants, livestock, wildlife, and human disturbance with soils, climate and other factors and the use of range management principles on rangeland ecosystems. Range Science at NDSU is a discipline that focuses on the scientific study of rangelands, grasslands, prairies, wetlands and grazed forests of semi-arid regions in order to manage the natural renewable resources for optimum benefit and environmental balance.

Kevin Sedivec, Ph.D.

Professor and Program Leader

Range Sciences

Hultz Hall, Room 100F

701.231.7647

Scan this image to your

kevin.sedivec@ndsu.edu

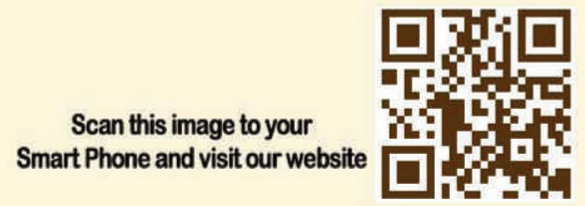

